\title{
Frequency of geohelminths in public squares in Pelotas, RS, Brazil
}

\author{
Frequência de geohelmintos em praças públicas de Pelotas, RS, Brasil \\ Micaele Quintana de Moura ${ }^{1}$; Sabrina Jeske ${ }^{1}$; Juliana Nunes Vieira ${ }^{1 *}$; \\ Tiago Gallina Corrêa ${ }^{1}$; Maria Elisabeth Aires Berne ${ }^{1}$; Marcos Marreiro Villela ${ }^{1}$
}

${ }^{1}$ Departamento de Microbiologia e Parasitologia, Instituto de Biologia, Universidade Federal de Pelotas - UFPel, Capão do Leão, RS, Brasil

Received March 28, 2012

Accepted July 17, 2012

\begin{abstract}
The frequency of parasitic contamination of public areas in the municipality of Pelotas, state of Rio Grande do Sul, Brazil, was studied between June 2010 and May 2011, when soil samples were collected from eight city squares. Out of 400 samples submitted to centrifugal floatation technique in solution of sodium dichromate with density of 1.35 , 176 (44\%) proved positive for at least one parasite; 29 (16.5\%) samples were multi-infested. The results showed that there was a significant soil contamination rate in all the parks included in the study. The positivity rate was higher for hookworms eggs (13.5\%) and Toxocara eggs (8.8\%); Trichuris, Ascaris and Capillaria eggs were also detected. This study shows the risks to which the population is exposed in relation to zoonotic geohelminths, and suggests that sanitation and health education measures should be implemented in the municipality.
\end{abstract}

Keywords: Helminths, environmental contamination, Toxocara, hookworms, eggs.

\section{Resumo}

A frequência de contaminação parasitária de áreas públicas de Pelotas, Rio Grande do Sul, Brasil, foi avaliada entre junho de 2010 e maio de 2011, com coletas mensais de amostras de solo de oito praças. Das 400 amostras submetidas à técnica de centrífugo-flutuação em solução de dicromato de sódio com densidade de 1,35, 176 (44\%) apresentaram pelo menos uma forma parasitária e, das amostras positivas, 29 (16,5\%) estavam poliparasitadas. Os resultados demonstraram relevante índice de contaminação do solo em todas as praças avaliadas, com maiores índices de positividade para ovos de ancilostomídeos (13,5\%) e ovos de Toxocara $(8,8 \%)$, sendo também identificados ovos de Trichuris, Ascaris e Capillaria. O estudo demonstrou a contaminaçáo ambiental de praças públicas e os riscos a que a populaçáo está exposta em relação a doenças causadas por geoparasitos zoonóticos e sugere que medidas de saneamento e educação em saúde devem ser implementadas no município.

Palavras-chave: Helmintos, contaminaçáo ambiental, Toxocara, Ancilostomídeos, ovos.

Soil can be a transmission route for various parasitic diseases (ALVES LIMA et al., 2007; MANDARINO-PEREIRA et al., 2010). Contamination of public parks by dog, cat and even human feces is a public health hazard due to the possibility of disease transmission, among which visceral larva migrans, cutaneous larva migrans, ascariasis, trichuriasis and other helminth diseases transmitted by contact with either contaminated soil or contaminated food (HOTEZ; WILKINS, 2009; BOWMAN et al., 2010).

In many Brazilian cities, as well as in those in other emerging countries, a large dog population runs at large on the streets and public parks, together with many animals that are brought by

\section{${ }^{*}$ Corresponding author: Juliana Nunes Vieira}

Departamento de Microbiologia e Parasitologia, Instituto de Biologia,

Universidade Federal de Pelotas - UFPel, Campus Capão do Leão, s/n,

CEP 96001-970, Capão do Leão, RS, Brasil

e-mail: jujununesvieira@yahoo.com.br owners (GUIMARÁES et al., 2005; NEVES; MASSARA, 2009; GALLINA et al., 2011). Dogs defecate in these places, thus contaminating the soil, onto which they can eliminate thousands of helminth eggs per gram of feces. These eggs, because of the consistency of their outer cuticle, remain viable in the environment for long periods, thus exposing the human population, especially children, to the risk of infection and development of parasitic diseases (SANTARÉM et al., 1998). Among humans, infection occurs most commonly in children from one to five years of age whose leisure activities and neglect of hygiene often lead to ingestion of parasites from contaminated environments (TORGERSON; MacPHERSON, 2011).

The nematode Toxocara canis stands out among those found in the soil. This parasite is often identified as the causative agent of visceral larva migrans and ocular larva migrans (HOTEZ; WILKINS, 2009; SVIBEN et al., 2009), and it may even result in central 
nervous system alterations (TORGERSON; MacPHERSON, 2011). Other parasites, such as Ascaris lumbricoides, Trichuris spp. and some protozoa, are also found in different soils, since human intestinal parasites may contaminate the environment with eggs, larvae and cysts when human waste is not adequately disposed of and treated, and consequently contaminates water, soil and food (NEVES; MASSARA, 2009; PULLAN et al., 2011). Studies on environmental contamination are the key to understanding the level of exposure to parasites that the population is subjected to. It is known that such studies must be associated with educational measures aimed at controlling endemic infectious and parasitic diseases so as to reduce their occurrence and, most importantly, reduce their harmful effects on the exposed population (GUIMARÃES et al., 2005).

The area of this study, located in a southern Brazilian municipality, is a risk zone where soil contamination by Toxocara spp. and hookworms has been confirmed by other studies (VILLELA et al., 2009; GALLINA et al., 2011). However, no studies had so far focused on the parks and squares of this area, where stray domestic animals are often found in children's playgrounds. The aim of the present study was to estimate the rate of occurrence of helminth eggs and larvae in soil samples collected from public parks in the municipality of Pelotas, state of Rio Grande do Sul, southern Brazil, with a special focus on zoonosis-causing agents.

This study was conducted in the city of Pelotas, southern Brazil, between June 2010 and May 2011. Two hundred gram soil samples were collected from ten different sites presenting circulation of people and dogs in each of the eight major parks in the municipality. It is important to note that there are 38,000 stray dogs and cats in the municipality of Pelotas (information supplied by the zoonosis control sector, Federal University of Pelotas).

All points that presented a possible risk of animal and human contamination were sampled. All the parks included in the study have significant numbers of human visitors every day and, on occasion, stray dogs. The ten samples from each public square were obtained from all quadrants and the central region. Each sample was obtained from an area of approximately $2 \mathrm{~m}^{2}$ and reached a depth of up to $2 \mathrm{~cm}$ from the soil surface. Parks with low numbers of human visitors or that did not include leisure facilities such as children's playgrounds and benches were not included in the study. The samples were collected in individually identified sterile plastic bags, which were sent to the Parasitology Laboratory of the Federal University of Pelotas, and were kept under refrigeration $\left(4^{\circ} \mathrm{C}\right)$ until they were processed, which occurred no later than 48 hours afterwards. In the laboratory, the samples were processed by means of the Caldwell \& Caldwell centrifugal quotation technique, as adapted by Pessoa and Martins (1988), and a sodium dichromate solution was used. Five samples from each of the ten collecting points in each square were prepared for reading, making a total of 50 evaluations, or a total of 400 samples from all of the eight squares included in the study.

The preparations were examined under an optical microscope at $40 \times$ magnification. Important structures were identified by means of morphological examination and micrometry. We also analyzed the shape of the membrane and the size of the eggs, and for the larvae, the mouth, esophagus and tail were examined. The data obtained were analyzed using the chi-square test $\left(\chi^{2}\right)$ to check for statistically significant differences. The Minitab software (version 18) was used. Explanations and additional information on the research were given to people who were at these public places on the sample collection days.

The results obtained showed that there was a significant contamination rate of the soil in all the parks included in the study. Out of the 400 samples analyzed, $44 \%$ (176) proved to be positive for at least one parasite. The highest positivity rate was in relation to hookworms eggs (13.5\%), followed by Toxocara (8.8\%), Trichuris (6.8\%), Strongyloidea superfamily (excluding hookworms) (3.5\%), Ascaroidea superfamily (excluding the Ascaris genus) (3.5\%), Ascaris (0.8\%) and Capillaria (0.3\%) (Table 1). Out of 176 positive samples, $29(16.5 \%)$ were multi-infested. In these, the most common association found was between hookworms and Toxocara eggs (2.7\%) (Table 2).

Toxocara, hookworms, Ascaris and Trichuris embryonated eggs were found, but most of the samples consisted of non-embryonated eggs. Non-viable eggs (deformed and/or without germ cells) were also diagnosed.

Table 1. Helminths diagnosed in soil samples from public parks in the municipality of Pelotas, southern Brazil, between 2010 and 2011.

\begin{tabular}{ccc}
\hline $\begin{array}{c}\text { Helminths with } \\
\text { zoonotic potential }\end{array}$ & Positive samples & $\%$ \\
\hline Hookworms & 54 & 13.5 \\
Toxocara & 35 & 8.8 \\
Trichuris & 27 & 6.8 \\
Strongyloidea $\left(^{*}\right)$ & 14 & 3.5 \\
Ascaroidea $\left(^{* *}\right)$ & 14 & 3.5 \\
Ascaris & 03 & 0.8 \\
Capillaria & 01 & 0.3 \\
\hline
\end{tabular}

*Eggs belonging to the Strongyloidea excluding hookworms.

**Eggs belonging to the Ascaroidea excluding Ascaris. \% percentage.

Table 2. Parasite associations diagnosed in soil samples from public parks in the municipality of Pelotas, southern Brazil, between 2010 and 2011.

\begin{tabular}{|c|c|c|}
\hline Associations found & $\begin{array}{l}\text { Positive } \\
\text { samples }\end{array}$ & $\%$ \\
\hline Hookworms + Toxocara & 6 & 20.7 \\
\hline Hookworms + Trichuris & 4 & 13.8 \\
\hline Toxocara + Trichuris & 4 & 13.8 \\
\hline Trichuris + Strongyloidea $\left(^{*}\right)$ & 3 & 10.3 \\
\hline Toxocara + Ascaroidea $\left({ }^{* *}\right)$ & 2 & 6.9 \\
\hline Hookworms + Ascaroidea $\left({ }^{* *}\right)$ & 2 & 6.9 \\
\hline Toxocara + Ascaris & 1 & 3.4 \\
\hline Toxocara + Strongyloidea $(*)$ & 1 & 3.4 \\
\hline Hookworms + Toxocara + Trichuris & 1 & 3.4 \\
\hline Hookworms + Toxocara + Ascaris & 1 & 3.4 \\
\hline Hookworms + Toxocara + Strongyloidea $(*)$ & 1 & 3.4 \\
\hline Hookworms + Toxocara + Ascaroidea $\left(^{*}\right)$ & 1 & 3.4 \\
\hline Toxocara + Trichuris + Strongyloidea $(*)$ & 1 & 3.4 \\
\hline Hookworms + Trichuris + Hookworms larvae & 1 & 3.4 \\
\hline Total & 29 & 100 \\
\hline
\end{tabular}

*Eggs belonging to the Strongyloidea excluding hookworms

**Eggs belonging to the Ascaroidea excluding Ascaris. \% percentage. 
With regard to the different months/seasons in which the collections were made, there were no statistically significant differences in the numbers of positive findings in the parks ( $p>0.05$ ), since all the collections contained contaminated parasites, regardless of weather conditions. However, when the eight parks were considered separately, the positivity ranged from 22 to $68 \%$ for the fifty collection sites in each park ( $p>0.05$ ). Dogs were seen in all areas, including during the collection times, with access to all park areas, since there are no fences.

Helminths transmitted by contaminated soil are thought to have been a public health hazard since ancient times, and remain a relevant public health issue in developing countries. Nonetheless, they are classified as neglected illness-causing agents because of the low priority that has been given to them (HOTEZ et al., 2008; HOTEZ; WILKINS, 2009). In the present study, helminth eggs with zoonotic potential were found in all the parks investigated. Hookworms and Toxocara spp. were the most common parasites, and it is worth mentioning that these parasites had already been identified as contaminating agents at beaches and schools in this region (VILLELA et al., 2009; GALLINA et al., 2011).

Occurrences of Toxocara eggs are commonplace at public locations throughout Brazil, and most studies on this topic have pointed out that there is a significant positivity rate in public parks and squares. In a study conducted in Botucatu, SP (SANTARÉM et al., 1998), six out of the ten parks and squares analyzed were contaminated, and the positive sampling rate for Toxocara egg occurrence was $17.5 \%$. In a study in southern Brazil that aimed to investigate differences in positivity according to seasonal variations, Tiyo et al. (2008) observed a 53\% contamination rate among 373 samples analyzed, without seasonal variation.

Most studies in this region have indicated that there is a lack of control over stray animals, as well as a lack of action towards prevention of the parasitic diseases that these animals can transmit. Moreover, it has been demonstrated that dogs can carry viable Toxocara eggs on their fur (AMARAL et al., 2010). Stray or lone dogs were spotted in every square where this study was conducted; on some occasions, dog feces were found in flower beds and even in children's playgrounds. Parasites of the Ancylostoma and Toxocara genera are usually diagnosed in stray dogs in endemic countries (OKOYE et al., 2011), and presence of these nematodes may result in both cutaneous and visceral larva migrans. These are common diseases in the Americas that nevertheless have been neglected by public health agencies (HOTEZ; WILKINS, 2009; BOWMAN et al., 2010). According to Cassenote et al. (2011), protective fencing in parks would be beneficial with regard to cleaning up soil feces, thereby decreasing contamination by as much as tenfold. This is a procedure that needs to be developed and forwarded to the authorities in charge of such public facilities.

Although a statistically significant difference was found when the parks were analyzed separately, significant positivity rates were observed in all of them. The lowest occurrence of zoonotic agents was seen in $22 \%$ of the collection sites of a park located in the north of the municipality where stray dogs had also been seen. Parasites were diagnosed independently of the month of soil sample collection. Regularity of contamination had already been identified in similar studies in other regions (NUNES et al., 2000; TIYO et al., 2008). Although it is known that the occurrence and distribution of zoonotic helminths are linked to climate changes (JENKINS et al., 2011), the great resistance of nematode eggs against desiccation, which is considered to be an adaptive survival mechanism for this group of organisms, may account for their presence throughout the different seasons in this study (MANDARINO-PEREIRA et al., 2010).

The present study analyzed contamination by various helminths in the soil of public parks. The highest helminth percentages and significance found were in relation to Ancylostoma sp., Toxocara sp. and Trichuris sp. Ascaris sp. eggs were also found: even though the occurrence rate was low, this is an important public health hazard. The results obtained demonstrate the potential risk of transmission of some parasitic diseases that the population is exposed to when using these public facilities, especially children. Thus, this emphasizes the need to implement effective control measures, since responsible ownership of pets and placement of fences or barriers can prevent or restrict the presence of these animals in sandboxes and other public recreational areas.

\section{References}

Alves Lima AM, Alves LC, Faustino MAG, Lira NMS, Magalhães A, Lima $\mathrm{MM}$, et al. Búsqueda de huevos de anquilostomideos y toxocarídeos en el suelo de residencias y escuelas en el barrio de dois irmáos, Recife-PE (Brasil). Parasitol Latinoam 2007; 62(1-2): 89-93.

Amaral HLC, Rassier GL, Pepe MS, Gallina T, Villela MM, Nobre $\mathrm{MO}$, et al. Presence of Toxocara canis eggs on the hair of dogs: a risk factor for Visceral Larva Migrans. Vet Parasitol 2010; 174(1-2): 115-118. PMid:20728996. http://dx.doi.org/10.1016/j.vetpar.2010.07.016

Bowman DD, Montgomery SP, Zajac AM, Eberhard ML, Kazacos KR. Hookworms of dogs and cats as agents of cutaneous larva migrans. Trends Parasitol 2010; 26(4): 162-167. PMid:20189454. http://dx.doi. org/10.1016/j.pt.2010.01.005

Cassenote AJF, Pinto Neto JM, Lima-Catelani ARA, Ferreira AW. Contaminação do solo por ovos de geo-helmintos com potencial zoonótico na municipalidade de Fernandópolis, Estado de São Paulo, entre 2007 e 2008. Rev Soc Bra Med Trop 2011; 44(3):371-374. PMid:21552740. http://dx.doi.org/10.1590/S0037-86822011005000026

Gallina T, Silva MAMP, Castro LLD, Emília EW, Villela MM, Berne MEA. Presence of eggs of Toxocara spp. and hookworms in a student environment in Rio Grande do Sul, Brazil. Rev Bras Parasitol Vet 2011; 20(2):41-42. http://dx.doi.org/10.1590/ S1984-29612011000200016

Guimarães AM, Alves EGL, Rezende GF, Rodrigues MC. Ovos de Toxocara sp. e larvas de Ancylostoma sp. em praça pública de Lavras, MG. Rev Saúde Pública 2005; 39(2): 293-295. PMid:15895151. http://dx.doi. org/10.1590/S0034-89102005000200022

Hotez PJ, Brindley PJ, Bethony JM, King CH, Pearce EJ, Jacobson J. Helminth infections: the great neglected tropical diseases. J Clin Invest 2008; 118(4): 1311-1321. PMid:18382743 PMCid:2276811. http://dx.doi.org/10.1172/JCI34261

Hotez PJ, Wilkins PP. Toxocariasis: America’s Most Common Neglected Infection of Poverty and a Helminthiasis of Global Importance? PLoS Negl Trop Dis 2009; 3(3): e4. PMid:19333373 PMCid:2658740. http:// dx.doi.org/10.1371/journal.pntd.0000400 
Jenkins EJ, Schurer JM, Gesy KM. Old problems on a new playing field: Helminth zoonoses transmitted among dogs, wildlife, and people in a changing northern climate. Vet Parasitol 2011; 182(1): 54-69. PMid:21802208. http://dx.doi.org/10.1016/j.vetpar.2011.07.015

Mandarino-Pereira A, De Sousa FS, Lopes CW, Pereira MJ. Prevalence of parasites in soil and dog feces according to diagnostic tests. Vet Parasitol 2010; 170(1-2): 176-181. PMid:20226595. http://dx.doi. org/10.1016/j.vetpar.2010.02.007

Neves RLS, Massara CL. Contaminação do solo de áreas comunitárias do município de Caratinga, MG, Brasil, por ovos de Toxocara sp. e cistos de Entamoeba sp. Rev Patol Trop 2009; 38(2): 126-130.

Nunes CM, Pena FC, Negrelli GB, Anjo CGS, Nakano MM, Stobbe NS. Ocorrência de larva migrans na areia de áreas de lazer das escolas municipais de ensino infantil, Araçatuba, SP, Brasil. Rev Saúde Pública 2000; 34(6): 656-658. PMid:11175613. http://dx.doi. org/10.1590/S0034-89102000000600015

Okoye IC, Obiezue NR, Okorie CE, Ofoezie IE. Epidemiology of intestinal helminth parasites in stray dogs from markets in south-eastern Nigeria. J Helminthol 2011; 85(4): 415-420. PMid:21144127. http:// dx.doi.org/10.1017/S0022149X10000738

Pessoa SB, Martins AV. Noçôes sobre as principais técnicas usadas em parasitologia. In: Pessoa SB, Martins AV. Parasitologia Médica. Rio de Janeiro: Guanabara Koogan; 1988. p. 814-854
Pullan RL, Gething PW, Smith JL, Mwandawiro CS, Sturrock HJW, Gitonga CW, et al. Spatial Modelling of Soil-Transmitted Helminth Infections in Kenya: A Disease Control Planning Tool. PLoS Negl Trop Dis 2011; 5(2): e958. PMid:21347451 PMCid:3035671. http://dx.doi. org/10.1371/journal.pntd.0000958

Santarém VA, Sartor IF, Bergamo FMM. Contaminaçáo, por ovos de Toxocara spp, de parques e praças públicas de Botucatu, São Paulo, Brasil. Rev Soc Bras Med Trop 1998; 31(6): 529-32. PMid:9859696. http:// dx.doi.org/10.1590/S0037-86821998000600004

Sviben M, Cavlek TV, Missoni EM, Galinovic GM. Seroprevalence of Toxocara canis infection among asymptomatic children with eosinophilia in Croatia. J Helminthol 2009; 83(4):369-371. PMid:19460194. http:// dx.doi.org/10.1017/S0022149X09381213

Tiyo R, Guedes TA, Falavigna DLM, Falavigna-Guilherme AL. Seasonal contamination of public squares and lawns by parasites with zoonotic potential in southern Brazil. J Helminthol 2008; 82(1): 1-6. PMid:18053297. http://dx.doi.org/10.1017/S0022149X07870829

Torgerson PR, MacPherson CNL. The socioeconomic burden of parasitic zoonosis: Global trends. Vet Parasitol 2011; 182(1): 79-95. PMid:21862222. http://dx.doi.org/10.1016/j.vetpar.2011.07.017

Villela MM, Pepe MS, Ferraz ML, Morais NCM, Araújo AB, Ruas JL, et al. NOTA: Contaminaçáo ambiental da orla da Laguna dos Patos (Pelotas, RS, Brasil), por parasitos com potencial zoonótico. Vittalle 2009; 20(2): 69-74. 